TITLE:

\title{
Magnetic resonance imaging of tumor with a self-traceable polymer conjugated with an antibody fragment.
}

\section{AUTHOR(S):}

Yamada, Hisatsugu; Hasegawa, Yoshinori; Suzuki, Yuki; Imai, Hirohiko; Matsuda, Tetsuya; Kimura, Yu; Toshimitsu, Akio; Aoyama, Yasuhiro; Kondo, Teruyuki

\section{CITATION:}

Yamada, Hisatsugu ... [et al]. Magnetic resonance imaging of tumor with a self-traceable polymer conjugated with an antibody fragment.. Bioorganic \& medicinal chemistry letters 2015, 25(13): 2675-2678

\section{ISSUE DATE:}

2015-07-01

URL:

http://hdl.handle.net/2433/201953

\section{RIGHT:}

(C) 2015. This manuscript version is made available under the CC-BY-NC-ND 4.0 license

http://creativecommons.org/licenses/by-nc-nd/4.0/; The full-text file will be made open to the public on 1 July 2017 in accordance with publisher's 'Terms and Conditions for Self-Archiving'.; This is not the published version. Please cite only the published version.; この論文は出版社版でありません。引用の際には出版社版をご確認ご利用ください。 


\section{Graphical Abstract}

To create your abstract, type over the instructions in the template box below.

Fonts or abstract dimensions should not be changed or altered.

\section{Magnetic Resonance Imaging of Tumor with a Self-Traceable Polymer Conjugated with an Antibody Fragment}

Leave this area blank for abstract info.

Hisatsugu Yamada, Yoshinori Hasegawa, Yuki Suzuki, Hirohiko Imai, Tetsuya Matsuda, Yu Kimura, Akio Toshimitsu, Yasuhiro Aoyama,* and Teruyuki Kondo*

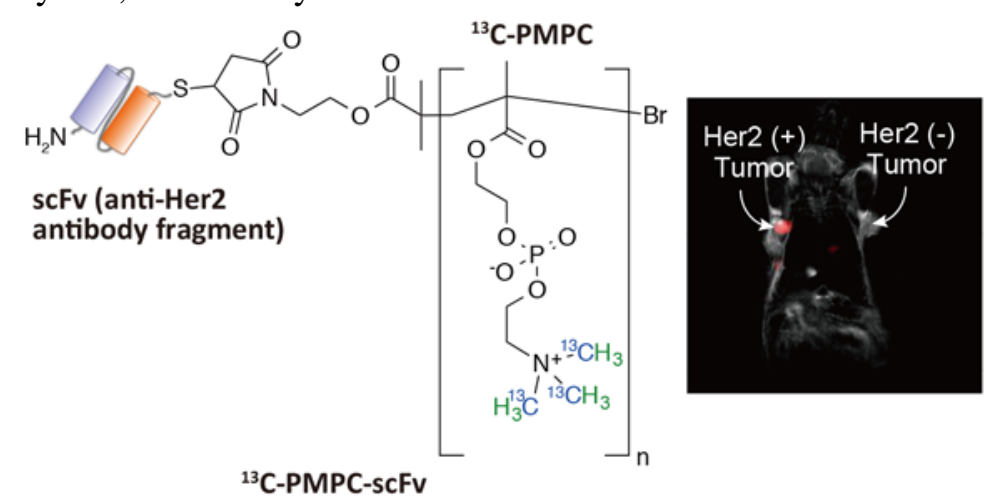




\title{
Magnetic Resonance Imaging of Tumor with a Self-Traceable Polymer Conjugated with an Antibody Fragment
}

\author{
Hisatsugu Yamada ${ }^{\text {a }}$, Yoshinori Hasegawa ${ }^{\text {b }}$, Yuki Suzuki ${ }^{\text {b }}$, Hirohiko Imai ${ }^{\text {c }}$, Tetsuya Matsuda ${ }^{c}$, Yu Kimura \\ d, Akio Toshimitsu ${ }^{\text {b,e }}$, Yasuhiro Aoyama ${ }^{\text {f, }}$, and Teruyuki Kondo ${ }^{\mathrm{a}, \mathrm{b}, *}$ \\ ${ }^{a}$ Advanced Biomedical Engineering Research Unit, Center for the Promotion of Interdisciplinary Education and Research, Kyoto University, Katsura, Nishikyo- \\ ku, Kyoto 615-8510, Japan \\ ${ }^{b}$ Department of Energy and Hydrocarbon Chemistry, Graduate School of Engineering, Kyoto University, Katsura, Nishikyo-ku, Kyoto 615-8510, Japan \\ ${ }^{c}$ Department of Systems Science, Graduate School of Informatics, Kyoto University, Yoshida-honmachi, Sakyo-ku, Kyoto 606-8501, Japan \\ ${ }^{d}$ Research and Educational Unit of Leaders for Integrated Medical System, Center for the Promotion of Interdisciplinary Education and Research, Kyoto \\ University, Nishikyo-ku, Kyoto 615-8510, Japan \\ ${ }^{e}$ Division of Multidisciplinary Chemistry, Institute for Chemical Research, Kyoto University, Gokanosho, Uji, Kyoto 611-0011, Japan \\ ${ }^{f}$ Kyoto University, Katsura, Nishikyo-ku, Kyoto 615-8510, Japan
}

\section{ARTICLE INFO}

\section{Article history:}

Received

Revised

Accepted

Available online

\section{Keywords:}

Tumor imaging

MRI

Self-traceable polymer

Anti-Her2 antibody

Active targeting
A ${ }^{13} \mathrm{C}$-enriched phosphorylcholine polymer $\left({ }^{13} \mathrm{C}\right.$-PMPC) as a self-traceable MR (Magnetic Resonance) tag was conjugated with a fragment (scFv) of Herceptin, a clinical antibody against antigen Her2. When injected in model mice bearing Her2(+) (gastric) and Her2(-) (pancreatic) tumors, the antibody-tag conjugate ${ }^{13} \mathrm{C}-\mathrm{PMPC}-\mathrm{scFv}$ selectively accumulated in the Her2(+) tumor with a rapid build-up/decay (accumulation/clearance) profile and, with the use of the ${ }^{1} \mathrm{H}-$ ${ }^{13} \mathrm{C}$ double-resonance (heteronuclear correlation) technique, the Her2(+) gastric tumor was clearly MR imaged.

2009 Elsevier Ltd. All rights reserved.

$<$ This is an author version based on a template provided by Elsevier $>$
Current MRI (Magnetic Resonance Imaging) is based on the ${ }^{1} \mathrm{H}$ NMR relaxation of water and affords morphological images of the body. ${ }^{1}$ New directions of MRI focus on specific detection of tumors, which may be MR-imaged using either tumor targeters appropriately labeled with MR-responsible moieties such as ${ }^{19} \mathrm{~F}$ nuclei $^{2}$ or paramagnetic contrast agents, ${ }^{3}$ or specific signal amplification techniques such as hyperpolarization ${ }^{4}$ and chemical exchange saturation transfer ${ }^{5}$ for tumor-responsible small molecules such as pyruvate, $\mathrm{H}_{2} \mathrm{O}_{2}$, or glucose. Recently, we reported a different approach. ${ }^{6}$ A phosphorylcholine polymer (PMPC) enriched with ${ }^{13} \mathrm{C}$ at the methyl groups with a mean molecular weight of $M_{\mathrm{n}}=63,000$ was found to accumulate highly selectively and efficiently in the tumor (colon 26) of tumorbearing mice primarily by the so-called EPR (Enhanced Permeability and Retention) effect, and the tumor could be clearly MR-visualized with this ${ }^{13} \mathrm{C}$-concentrated polymeric nano-probe by the ${ }^{1} \mathrm{H}-{ }^{13} \mathrm{C}$ double-resonance ${ }^{7}$ (heteronuclear correlation) technique. ${ }^{6 c}$ This probe thus provides a novel example of a self-traceable EPR polymer that is free from foreign labeling. However, there are still some issues that need to be addressed if this probe is to have wider applicability as a tumor imager. One issue is the slowness of accumulation and clearance. Another involves the general utility of the EPR effect ${ }^{8}$, i.e., the size-allowed invasion and retention of nano-particles in tumor tissues which usually have a defective vascular wall with a wide opening and undeveloped lymphatic drainage. Although the EPR effect has been widely used for the passive targeting of tumors, ${ }^{9}$ the EPR-susceptibility of tumor tissues depends on the type of tumor. ${ }^{10}$ While colon 26, a mouse rectal cancer cell line, is highly susceptible to EPR, this is not necessarily true for other types of tumors. ${ }^{11}$ In the present work, we prepared a conjugate of ${ }^{13} \mathrm{C}$ PMPC as an MR signal generator with an antibody fragment as an active tumor targeter, and investigated the performance of this conjugate with the above issues in mind. We report here that the antibody-functionalized probe can selectively image an antibody- 


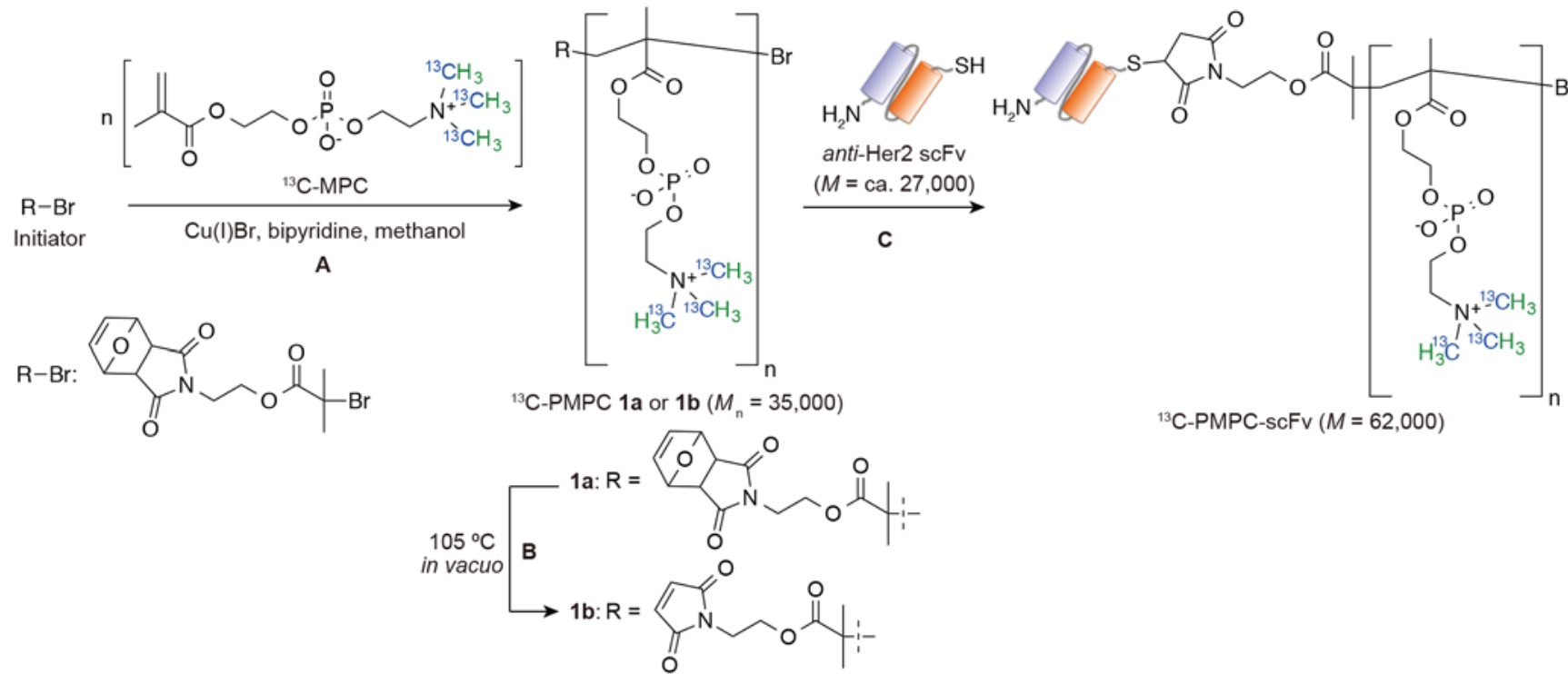

Scheme 1. Preparation of ${ }^{13} \mathrm{C}-\mathrm{PMPC}-\mathrm{scFv}$. A, atom-transfer radical polymerization of monomer ${ }^{13} \mathrm{C}-\mathrm{MPC}$ to afford polymer ${ }^{13} \mathrm{C}-\mathrm{PMPC} \mathbf{1 a}\left(M_{\mathrm{n}}=35,000\right)$. B retro-Diels Alder reaction of protected polymer $\mathbf{1 a}$ to give deprotected one ${ }^{13} \mathrm{C}-\mathrm{PMPC} \mathbf{1} \mathbf{b}$ with an active maleimide terminus. C, coupling of the maleimide of $\mathbf{1 b}$ with a fragment (scFv, $M=$ ca. 27,000) of Herceptin to afford ${ }^{13} \mathrm{C}-\mathrm{PMPC}-\mathrm{scFv}\left(M_{\mathrm{n}}=62,000\right)$.

(a)

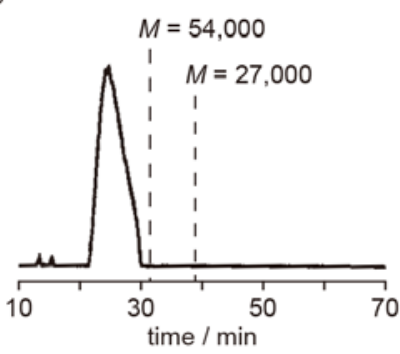

(c)

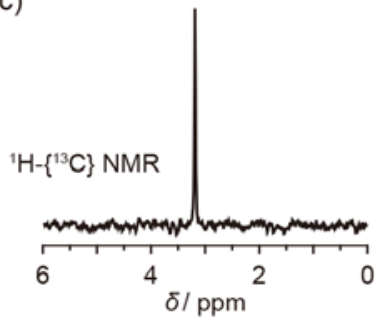

(b)

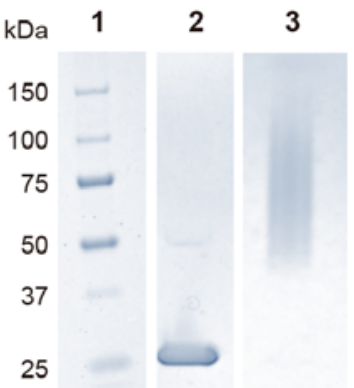

(d)

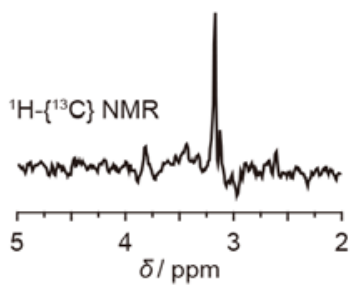

Figure 1. (a) GPC trace for ${ }^{13} \mathrm{C}-\mathrm{PMPC}-\mathrm{scFv}$. Retention times for $\mathrm{scFv}(M=$ $27,000)$ and its S-S (disulfide) dimer $(M=54,000)$ (see Supplementary Information) are also indicated. (b) SDS-PAGE analysis for ${ }^{13} \mathrm{C}-\mathrm{PMPC}$-scFv. Lane 1, molecular-weight marker. Lane 2, monomeric scFv ( $M=$ ca. $27 \mathrm{kDa})$. Lane 3, ${ }^{13} \mathrm{C}$-PMPC-scFv $(M=62 \mathrm{kDa})$. The broad band observed for ${ }^{13} \mathrm{C}-$ PMPC-scFv is due to molecular-weight distribution $\left(M_{\mathrm{w}} / M_{\mathrm{n}}=1.4\right)$ for the PMPC moiety. (c) One-dimensional ${ }^{1} \mathrm{H}-\left\{{ }^{13} \mathrm{C}\right\}$ double-resonance NMR spectrum for ${ }^{13} \mathrm{C}$-PMPC-scFv in $\mathrm{D}_{2} \mathrm{O}$, showing a single signal for the ${ }^{13} \mathrm{C}-$ enriched methyl protons. The spectrum was obtained at $25^{\circ} \mathrm{C}$ with a Bruker Avance 700 spectrometer equipped with a $5 \mathrm{~mm}$ TCI CryoProbe in a similar manner as reported previously. ${ }^{6 c}$ (d) Ex vivo double-resonance NMR spectrum of the Her2(+) tissue removed from a probe-administered mouse at a time point of $48 \mathrm{~h}$ from injection of the probe.

responsive but otherwise less EPR-susceptible tumor with a rapid build-up/decay profile.

Methacryloyloxyethylphosphorylcholine (MPC) enriched with ${ }^{13} \mathrm{C}$ at the choline methyl groups was polymerized under the atom-transfer radical polymerization (ATRP) conditions ${ }^{12}$ using furan-protected maleimide bromide ( $\mathrm{R}-\mathrm{Br})$ as an initiator and $\mathrm{CuBr} / 2,2$ '-bipyridine as a catalyst, according to the scheme

$\mathrm{n}(\mathrm{MPC})+\mathrm{R}-\mathrm{Br} \rightarrow \mathrm{R}-(\mathrm{MPC}) \mathrm{n}-\mathrm{Br}$ (Scheme 1$)^{6 \mathrm{c}}$. The polymer thus obtained $\left({ }^{13} \mathrm{C}-\mathrm{PMPC}\right)$ had a mean molecular weight of $M_{\mathrm{n}}=$ $35,000(\mathrm{n}=118)$ and a polydispersity index of $M_{\mathrm{w}} / M_{\mathrm{n}}=1.4$. This was subjected to coupling with a fragment (scFv) of Herceptin, a well-known clinical antibody against antigen Her2 that is expressed in breast cancer as well as gastric cancer. ${ }^{13}$ The actual fragment used (scFv) was a 257-amino acid sequence (from M1 to C257) that contained fragments of the heavy and light chains of Herceptin, conjugated with a nonapeptide $\left(\mathrm{H}_{6} \mathrm{G}_{2} \mathrm{C}\right)$ composed of a His-tag $\left(\mathrm{H}_{6}\right)$ linked with a tripeptide glycine-glycine-cysteine $\left(\mathrm{G}_{2} \mathrm{C}\right)$ at the C-terminus (Supplementary Information for details). ${ }^{14}$ The genetically engineered single-chain fragment variable ( $\mathrm{scFv}, M=$ ca. $27 \mathrm{kDa}$ ) was expressed in E. coli and purified by His-tag-targeted affinity chromatography. For polymer-antibody coupling, ${ }^{13} \mathrm{C}$-PMPC was carefully heated in vacuo at $105{ }^{\circ} \mathrm{C}$ in the absence of any solvent to allow deprotection (retro-Diels Alder removal of the furan ring) of the terminal initiator moiety into an active maleimide form. Addition (Michael addition) of the terminal cysteine residue in $\mathrm{scFv}$ to the maleimide at a molar ratio of ${ }^{13} \mathrm{C}-\mathrm{PMPC} / \mathrm{scFV}=24.5$ afforded conjugate ${ }^{13} \mathrm{C}-\mathrm{PMPC}-\mathrm{scFv}$ with a mean molecular weight of $35,000+27,000=62,000$, which was freed from ${ }^{13} \mathrm{C}$-PMPC in excess on treatment with a His-tag column, purified by sizeexclusion chromatography (GPC) (Figure 1a), and characterized by electrophoresis (SDS-PAGE) (Figure 1b) and ${ }^{1} \mathrm{H}-\left\{{ }^{13} \mathrm{C}\right\}$ double-resonance NMR analysis (Figure 1c).

Antigen Her2 is known to be highly expressed in gastric cancer as well as in breast cancer, but not in pancreatic cancer. ${ }^{15}$ Thus, N87 (a human gastric cancer cell line) and SUIT2 (a human pancreatic cancer cell line) were used here as Her2(+) and Her2(-) tumor cells, respectively. ${ }^{16}$ Model mice were obtained by transplanting the Her2(+) and Her2(-) tumor cells at the right shoulder and the contralateral left shoulder, respectively, of healthy mice $(\sim 20 \mathrm{~g})$. Probe ${ }^{13} \mathrm{C}-\mathrm{PMPC}-\mathrm{scFV}(113.5 \mathrm{mg} / \mathrm{kg}=$ $1.83 \mu \mathrm{mol} / \mathrm{kg}$ body weight or $2.27 \mathrm{mg} / 20$-g mouse) was intravenously injected into the tail vein of tumor-bearing mice. In vivo MR images of the mice were taken under probe-optimized double-resonance $\left({ }^{1} \mathrm{H}-\left\{{ }^{13} \mathrm{C}\right\}\right)$ conditions in essentially the same manner as described elsewhere ${ }^{6 c}$ (Supplementary Information for details). Figure 2a shows a typical image (double-resonance image overlaid on a $T_{2}$-weighted single-resonance $\left({ }^{1} \mathrm{H}\right)$ morphological image $)^{17}$ taken at $22 \mathrm{~h}$ after administration of the 
probe. We can clearly see that (1) the Her2(+) gastric tumor is clearly visualized while the Her2(-) pancreatic tumor is hardly visible, and (2) there is no appreciable accumulation of the probe in the liver, although some unidentified, noise-looking spots are still noticed. The observed Her2(+)/Her2(-) selectivity is probably a consequence of scFv-mediated active targeting of the Her2(+) tumor by the probe, since the reference probe ${ }^{13} \mathrm{C}$-PMPC $\left(M_{\mathrm{n}}=35,000\right)$, which lacks in the antibody scFv moiety, shows no notable affinity for the Her2(+) tumor (Figure 2b). Figure 3 shows a rough time course of imaging of the tumor sites at $4 \mathrm{~h}$, $22 \mathrm{~h}$, and $46 \mathrm{~h}$. The Her2(+) site exhibits a monotonous decrease in image intensity with signal-to-noise ratios of $\mathrm{S} / \mathrm{N}=12.9,9.6$, and 4.1 at $4 \mathrm{~h}, 22 \mathrm{~h}$, and $46 \mathrm{~h}$, respectively. The Her2(-) site is just barely imageable at $4 \mathrm{~h}$, but then fades away in 1 day. Ex vivo measurements for the tumor sites removed from the probeadministered mouse clearly show selective accumulation of the probe in the Her2(+) tumor (Figure 1d). Even at a time point of $48 \mathrm{~h}$ from injection, the double-resonance signal of the probe in Her2(+) is twice as intense as that in Her2(-). ${ }^{18}$ (a)

$$
{ }^{13} \mathrm{C}-\mathrm{PMPC}-\mathrm{ScFV}
$$
$22 \mathrm{~h}$

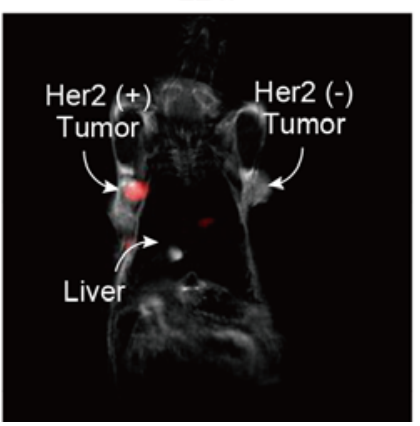

(b)

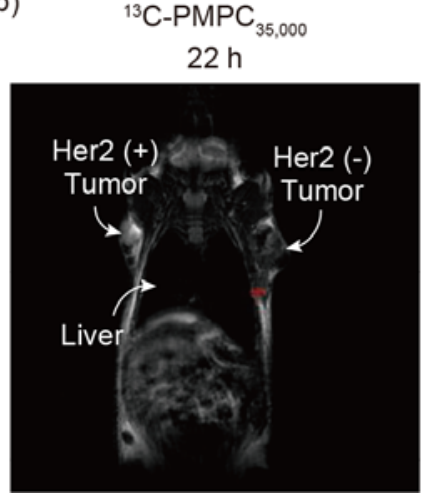

Figure 2. Probe-targeted double-resonance $\left({ }^{1} \mathrm{H}-\left\{{ }^{13} \mathrm{C}\right\}\right)$ MR images colored red by ImageJ software, overlaid on morphological images $\left(T_{2}\right.$-weighted single resonance). (a) Merged image for a tumor-bearing mouse bearing Her2(+) tumor (N87) at the right shoulder and Her2(-) tumor (SUIT2) at the contralateral left shoulder, at $22 \mathrm{~h}$ after the administration of ${ }^{13} \mathrm{C}$-PMPC-scFv (113.5 mg/kg = $1.83 \mu \mathrm{mol} / \mathrm{kg}$ body weight or $2.27 \mathrm{mg} / 20-\mathrm{g}$ mouse). (b) Merged image for a similar mouse administered ${ }^{13} \mathrm{C}-\mathrm{PMPC}_{35,000}(64 \mathrm{mg} / \mathrm{kg}=$ $1.83 \mu \mathrm{mol} / \mathrm{kg}$ body weight or $1.28 \mathrm{mg} / 20$-g mouse).
$4 \mathrm{~h}$

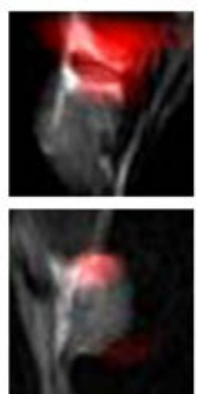

$22 \mathrm{~h}$

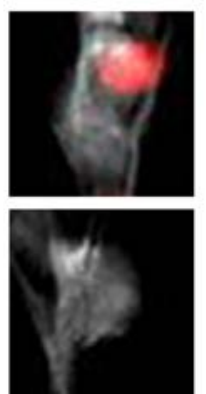

$46 \mathrm{~h}$

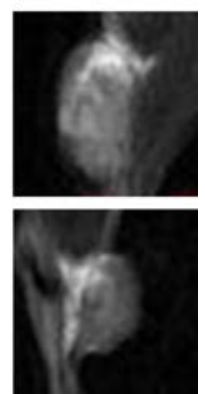

Figure 3. Time course of the change in merged images for the Her2(+) and Her2(-) tumor sites of a mouse administered probe ${ }^{13} \mathrm{C}-\mathrm{PMPC}-\mathrm{scF}$ as in Figure 2a.

The present active tumor-targeting may be compared with previously reported passive EPR tumor-targeting. There is a striking difference in the build-up/decay profiles. It takes $\sim 2$ days for the antibody-free probe ${ }^{13} \mathrm{C}$-PMPC $\left(M_{\mathrm{n}}=63,000\right)$ to settle in colon 26 tumor with a gradual increase in the $\mathrm{S} / \mathrm{N}$ ratio, and the probe accumulated in the tumor is stably retained therein for at least a week without undergoing clearance. ${ }^{6 c}$ In marked contrast, uptake of the antibody-functionalized probe ${ }^{13} \mathrm{C}-\mathrm{PMPC}-\mathrm{scFv}\left(M_{\mathrm{n}}\right.$ $=62,000)$ by the N87 tumor is rapid $(<4 \mathrm{~h})$, but the probe is cleared rather rapidly with a gradual decrease in the $\mathrm{S} / \mathrm{N}$ ratio within $\sim 2$ days (Figure 3, top). On the other hand, the two probes share a common characteristic. As in the case of ${ }^{13} \mathrm{C}$-PMPC, ${ }^{6 c}$ there is no appreciable nonspecific binding of probe ${ }^{13} \mathrm{C}$-PMPCscFv to normal organs, especially the liver (Figure 2a), which is often a major deposition site of nano-probes and nanomedicines. ${ }^{19}$ Formally, comparison of these two probes helps us to characterize the role of scFv. However, there is an obstacle. The two probes with similar molecular weights $(62,000$ vs 63,000) are far from analogous to each other with respect to size. Probe ${ }^{13} \mathrm{C}$-PMPC, which is plausibly free from aggregation, forms compact particles with a mean dynamic light scattering (DLS) size of $d_{\text {DLS }}=13.1 \pm 0.13 \mathrm{~nm}$ for ${ }^{13} \mathrm{C}-\mathrm{PMPC}_{63,000}$ as reported previously ${ }^{6 \mathrm{c}}$ or $d_{\mathrm{DLS}}=8.41 \pm 0.05 \mathrm{~nm}$ for ${ }^{13} \mathrm{C}-\mathrm{PMPC}_{35,000}$ (Figure 4b). In marked contrast, the antibody-functionalized probe ${ }^{13} \mathrm{C}$-PMPC-scFv62,000 is highly aggregated and forms large particles with $d_{\mathrm{DLS}}=175.3 \pm 2.5 \mathrm{~nm}$ (Figure 4a).

Size is an important factor that governs the pharmacokinetics of nano-particles. Roughly, EPR-relevant sizes are in the range of $10-100 \mathrm{~nm} \cdot{ }^{20}$ Smaller $(<10 \mathrm{~nm})$ and larger $(>100 \mathrm{~nm})$ particles are susceptible to clearance, respectively, by renal excretion ${ }^{21}$ and the reticuloendothelial systems, particularly via phagocytosis by macrophages distributed in various organs such as liver. ${ }^{22}$ Another factor to consider is biocompatibility. Phosphorylcholine comprises the head group of cell-membrane lipids (phosphatidylcholine), and polymers derived therefrom, including PMPC, are known to be biologically inert. ${ }^{23}$ They escape from phagocytosis, probably because they are not recognized as foreign bodies by macrophages. ${ }^{24}$ In this context, the biocompatibility of PMPC may primarily deactivate the macrophage/liver pathway for PMPC-based polymers regardless of their sizes. The rapid clearance of ${ }^{13} \mathrm{C}-\mathrm{PMPC}-\mathrm{scFv}$ is more difficult to explain at present. The antibody fragment scFv conjugated with a long polymer chain (PMPC), possibly via electrostatic interaction between them, might be susceptible to hydrolytic degradation to lose its affinity for the Her2(+) N87 site, although this is by no means conclusive and further rigorous investigation will be required. (a)

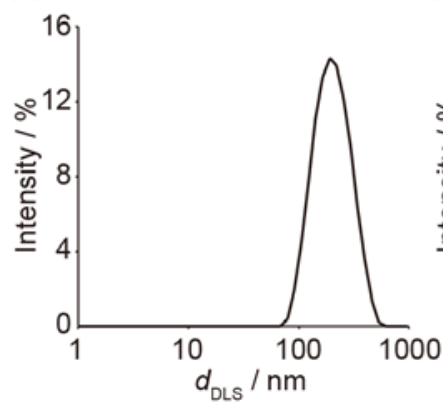

(b)

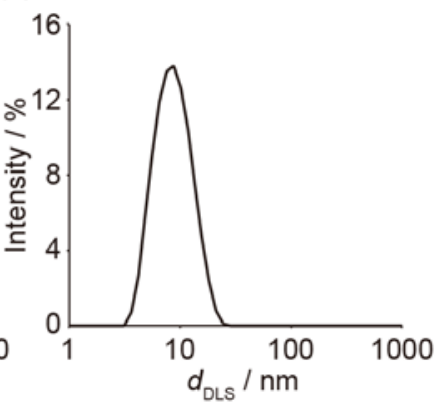

Figure 4. DLS size distribution profiles for (a) ${ }^{13} \mathrm{C}-\mathrm{PMPC}-\mathrm{scFv}\left(M_{\mathrm{n}}=\right.$ 62,000) $\left(2.3 \mathrm{mg} / \mathrm{mL}\right.$ in PBS) and (b) ${ }^{13} \mathrm{C}$-PMPC $\left(M_{\mathrm{n}}=35,000\right)(1 \mathrm{mg} / \mathrm{mL}$ in water).

In this work, we investigated how ${ }^{13} \mathrm{C}$-PMPC performs as a self-traceable MR tag for a tumor-targeting antibody. The antibody-tag conjugate exhibited expected antigen(+)/antigen(-) selectivity and MR-imaged the antigen(+) tumor with a rapid build-up/decay or accumulation/clearance profile. The dose of the present probe $(113.5 \mathrm{mg} / \mathrm{kg}=1.83 \mu \mathrm{mol} / \mathrm{kg})$ is comparable to (on a weight basis) or much lower (on a molar basis) than that of Magnevist $(74 \mathrm{mg} / \mathrm{kg}=0.1 \mathrm{mmol} / \mathrm{kg})$, a clinical contrast agent 
that is widely used in current MRI. The detection limit of imaging of the present ${ }^{13} \mathrm{C}$-PMPC-scFv probe would be $\sim 18 \mu \mathrm{M}$, ${ }^{25}$ which is slightly higher than the detection limit (several $\mu \mathrm{M}$ ) reported for a gadolinium contrast agent. ${ }^{26}$ The use of synthetic polymers as a tag may offer both advantages and disadvantages compared with small optical tags such as fluorophores. Synthetic polymers are also widely and uniquely used as carriers of drugs and genes ${ }^{27}$ and as stabilizers of clinical protein and nucleic acid medications. ${ }^{28}$ In this context, this work may represent a step toward the visualization of various delivery/localization events mediated by synthetic polymers. At the same time, this work revealed an unexpected problem: aggregation-free PMPC becomes highly aggregated upon modification with scFv, which $\left(d_{\mathrm{DLS}}=10.3 \mathrm{~nm}\right)$ alone supposedly does not aggregate. Phosphorylcholine polymer (PMPC) is zwitterionic, i.e., it is an ammonium-phosphate polybetaine. The scFv moiety seems to perturb the otherwise intramolecular/intrastrand electrostatic interaction of PMPC $^{29}$ and promote intermolecular/interstrand interaction thereof. Further work is now underway in our laboratories to gain deeper insight into the pharmacokinetics of the present and related PMPC probes and to shed more light on the effects of terminal substituents on the aggregation states of PMPC polymers.

\section{Acknowledgments}

This work was supported by the innovative Techno-Hub for Integrated Medical Bio-Imaging of the Project for Developing Innovation Systems, from the Ministry of Education, Culture, Sports, Science and Technology (MEXT), Japan, and partly by Grant-in-Aid No. 25350977 from JSPS, Japan. TK acknowledges financial support from JSPS Grant-in-Aid No. 15K01819, 15H01403, the Princess Takamatsu Cancer Research Fund, Magnetic Health Science Foundation, and SEI Group CSR Foundation. We thank Profs. Masahiro Shirakawa and Hidehito Tochio, and Drs. Shin Isogai, Kayo Imamura (Kyoto University) and Fumio Yamauchi (Canon Inc.) for their technical support and their kind gift of scFv used in this work. We also thank Prof. Shinsuke Sando (The University of Tokyo) for his valuable discussion.

\section{References and notes}

1. Sosnovik, D. E.; Weissleder, R. Curr. Opin. Biotechnol. 2007, 18, 4-10.

2. (a) Yu, J.-x.; Kodibagkar, V. D.; Cui, W.; Mason, R. P. Curr. Med. Chem. 2005, 12, 819-848; (b) Takaoka, Y.; Sakamoto, T.; Tsukiji, S.; Narazaki, M.; Matsuda, T.; Tochio, H.; Shirakawa, M.; Hamachi, I. Nat. Chem. 2009, 1, 557-561; (c) Rolfe, B. E.; Blakey, I.; Squires, O.; Peng, H.; Boase, N. R. B.; Alexander, C.; Parsons, P. G.; Boyle, G. M.; Whittaker, A. K.; Thurecht, K. J. J. Am. Chem. Soc. 2014, 136, 2413-2419; (d) Matsushita, H.; Mizukami, S.; Sugihara, F.; Nakanishi, Y.; Yoshioka, Y.; Kikuchi, K. Angew. Chem. Int. Ed. 2014, 53, 1008-1011.

3. Villaraza, A. J. L.; Bumb, A.; Brechbiel, M. W. Chem. Rev. 2010 110, 2921-2959 and references therein.

4. (a) Day, S. E.; Kettunen, M. I.; Gallagher, F. A.; Hu, D.-E.; Lerche, M.; Wolber, J.; Golman, K.; Ardenkjaer-Larsen, J. H.; Brindle, K. M. Nat. Med. 2007, 13, 1382-1387; (b) Lippert, A. R.; Keshari, K. R.; Kurhanewicz, J.; Chang, C. J. J. Am. Chem. Soc. 2011, 133, 3776-3779.

5. (a) Zhang, S.; Trokowski, R.; Sherry, A. D. J. Am. Chem. Soc. 2003, 125, 15288-15289; (b) Walker-Samuel, S.; Ramasawmy, R.; Torrealdea, F.; Rega, M.; Rajkumar, V.; Johnson, S. P.; Richardson, S.; Gonçalves, M. G. C.; Parkes, H. G.; Årstad, E.; Thomas, D. L.; Pedley, R. B.; Lythgoe, M. F.; Golay, X.; Nat. Med. 2013, 19, 1067-1072.

6. (a) Yamaguchi, K.; Ueki, R.; Yamada, H.; Aoyama, Y.; Nonaka, H.; Sando, S. Anal. Methods 2011, 3, 1664-1666; (b) Yamada, H.; Mizusawa, K.; Igarashi, R.; Tochio, H.; Shirakawa, M.; Tabata,
Y.; Kimura, Y.; Kondo, T.; Aoyama, Y.; Sando, S. ACS Chem. Biol. 2012, 7, 535-542; (c) Yamada, H.; Hasegawa, Y.; Imai, H.; Takayama, Y.; Sugihara, F.; Matsuda, T.; Tochio, H.; Shirakawa, M.; Sando, S.; Kimura, Y.; Toshimitsu, A.; Aoyama, Y.; Kondo, T. J. Am. Chem. Soc. 2015, 137, 799-806.

7. van Zijl, P. C. M.; Chesnick, A. S.; Despres, D.; Moonen, C. T. W.; Ruiz-Cabello, J.; van Gelderen, P. Magn. Reson. Med. 1993, 30, 544-551.

8. Matsumura, Y.; Maeda, H. Cancer Res. 1986, 46, 6387-6392.

9. (a) Harris, J. M.; Chess, R. B. Nat. Rev. Drug Discov. 2003, 2, 214-221; (b) Duncan, R. Nat. Rev. Cancer 2006, 6, 688-701. (c) Davis, M. E.; Chen, Z. G.; Shin, D. M. Nat. Rev. Drug Discov. 2008, 7, 771-782.

10. Duncan, R.; Sat-Klopsch, Y.-N.; Burger, A. M.; Bibby, M. C.; Fiebig, H. H.; Sausville, E. A. Cancer Chemother. Pharmacol. 2013, 72, 417-427.

11. Kano, M. R.; Bae, Y.; Iwata, C.; Morishita, Y.; Yashiro, M.; Oka, M.; Fujii, T.; Komuro, A.; Kiyono, K.; Kaminishi, M. Proc. Natl. Acad. Sci. U.S.A. 2007, 104, 3460-3465.

12. Lobb, E. J.; Ma, I.; Billingham, N. C.; Armes, S. P.; Lewis, A. L. J. Am. Chem. Soc. 2001, 123, 7913-7914.

13. Hudis, C. A. N. Engl. J. Med. 2007, 357, 36-51.

14. Carter, P.; Presta, L.; Gorman, C. M.; Ridgway, J. B.; Henner, D.; Wong, W. L.; Rowland, A. M.; Kotts, C.; Carver, M. E.; Shepard, H. M. Proc. Natl. Acad. Sci. U.S.A. 1992, 89, 4285-4289.

15. Vernimmen, D.; Gueders, M.; Pisvin, S.; Delvenne, P.; Winkler, R. Br J Cancer 2003, 89, 899-906.

16. (a) Tanner, M.; Hollen, M.; Junttila, T. T.; Kapanen, A. I.; Tommola, S.; Soini, Y.; Helin, H.; Salo, J.; Joensuu, H.; Sihvo, E.; Elenius, K.; Isola, J. Ann. Oncol. 2005, 16, 273-278. (b) Shimizu, Y.; Temma, T.; Hara, I.; Makino, A.; Yamahara, R.; Ozeki, E.-I.; Ono, M.; Saji, H. Nanomedicine: NBM 2014, 10, 187-195.

17. As detailed previously, ${ }^{6 c}$ double-resonance images are without slice selection and hence they are projections through the body. On the other hand, single-resonance $\left({ }^{1} \mathrm{H}\right)$ morphological images are tomographic (in-slice).

18. Contribution of endogenous choline derivatives would be negligible. In a previous work, ${ }^{6 c}$ we investigated in detail the detection limit of the imaging of 210 -mer ${ }^{13} \mathrm{C}$-PMPC $\left(M_{\mathrm{n}}=\right.$ 63,000 ) under double-resonance conditions with a scan time of 8.6 min. It was $\sim 10 \mu \mathrm{M}$ and hence $10 \times 210=2,100 \mu \mathrm{M}$ or $2.1 \mathrm{mM}$ for the monomeric ${ }^{13} \mathrm{C}$-choline unit. Choline derivatives are known to be abundantly distributed in the body at a mM (1-10 $\mathrm{mM}$ ) level ${ }^{18 \mathrm{a}}$ with a population of $0.1-0.01 \mathrm{mM}$ of naturalabundance ${ }^{13} \mathrm{C}$-cholines. This is far lower than the detection limit $(2.1 \mathrm{mM})$ shown above. Endogenous ${ }^{13} \mathrm{C}$-cholines could thus hardly be imaged by the present technique. (a) Dorrius, M. D.; Pijnappel, R. M.; Jansen-van der Weide, M. C.; Jansen, L.; Kappert, P.; Oudkerk, M.; Sijens, P. E. Radiology 2011, 259, 695703.

19. Cabral, H.; Matsumoto, Y.; Mizuno, K.; Chen, Q.; Murakami, M.; Kimura, M.; Terada, Y.; Kano, M. R.; Miyazono, K.; Uesaka, M.; Nishiyama, N.; Kataoka, K. Nat. Nanotech. 2011, 6, 815-823.

20. (a) Fox, M. E.; Szoka, F. C.; Fréchet, J. M. J. Acc. Chem. Res, 2009, 42, 1141-1151; (b) Petros, R. A.; DeSimone, J. M. Nat. Rev. Drug Discov. 2010, 9, 615-627.

21. Choi, H. S.; Liu, W.; Misra, P.; Tanaka, E.; Zimmer, J. P.; Itty Ipe, B.; Bawendi, M. G.; Frangioni, J. V. Nat. Biotechnol. 2007, 25, 1165-1170.

22. Ilium, L.; Davis, S. S.; Wilson, C. G.; Thomas, N. W.; Frier, M.; Hardy, J. G. Int. J. Pharm. 1982, 12, 135-146.

23. Lewis, A. L. Colloids Surf., B 2000, 18, 261-275.

24. Moro, T.; Takatori, Y.; Ishihara, K.; Konno, T.; Takigawa, Y.; Matsushita, T.; Chung, U.-I.; Nakamura, K.; Kawaguchi, H. Nat. Mater. 2004, 3, 829-836.

25. The detection (imageable) limit of the present ${ }^{13} \mathrm{C}-\mathrm{PMPC}-\mathrm{scFv}$ with a 118-mer PMPC moiety will be 2,100/118 $=18 \mu \mathrm{M}$, where $2,100 \mu \mathrm{M}$ is the detection limit for the monomeric ${ }^{13} \mathrm{C}$-choline unit. ${ }^{18}$

26. Hanaoka, K.; Lubag, A. J. M.; Castillo-Muzquiz, A.; Kodadek, T.; Sherry, A. D. Magn. Reson. Imaging 2008, 26, 608-617.

27. (a) Joralemon, M. J.; McRae, S.; Emrick, T. Chem. Commun. 2010, 46, 1377-1393; (b) Larson, N.; Ghandehari, H. Chem. Mater. 2012, 24, 840-853.

28. (a) Keefe, A. J.; Jiang, S. Nat. Chem. 2011, 4, 59-63; (b) Park, T. G.; Jeong, J. H.; Kim, S. W. Adv. Drug Deliv. Rev. 2006, 58, 467486.

29. Mahon, J.; Zhu, S. Colloid Polym. Sci. 2008, 286, 1443-1454 
